\title{
Estimates of genetic parameters for visual scores and their correlation with production and reproductive traits in Brahman cattle ${ }^{1}$
}

\author{
Tássia Souza Bertipaglia², Luis Orlando Duitama Carreño ${ }^{3}$, Carlos Henrique Cavallini \\ Machado $^{4}$, Cristiana Andrighetto ${ }^{5}$, Ricardo da Fonseca ${ }^{5}$
}

\author{
1 Research funded by FAPESP. \\ 2 Campus Experimental de Dracena - UD/UNESP, Dracena-SP, Brasil. \\ 3 Programa de Pós-graduação em Genética e Melhoramento Animal - FCAVIUNESP, Jaboticabal - SP, Brasil. \\ 4 Programa de Melhoramento Genético de Zebuínos - PMGZ/ABCZ, Uberaba - MG, Brasil. \\ 5 Departamento de Zootecnia - Campus Experimental de Dracena - UD/UNESP, Dracena - SP. Brasil.
}

\begin{abstract}
The objective of this study was to evaluate the association of visual scores of body structure, precocity and muscularity with production (body weight at 18 months and average daily gain) and reproductive (scrotal circumference) traits in Brahman cattle in order to determine the possible use of these scores as selection criteria to improve carcass quality. Covariance components were estimated by the restricted maximum likelihood method using an animal model that included contemporary group as fixed effect. A total of 1,116 observations of body structure, precocity and muscularity were used. Heritability was $0.39,043$ and 0.40 for body structure, precocity and muscularity, respectively. The genetic correlations were 0.79 between body structure and precocity, 0.87 between body structure and muscularity, and 0.91 between precocity and muscularity. The genetic correlations between visual scores and body weight at 18 months were positive $(0.77,0.57$ and 0.59 for body structure, precocity and muscularity, respectively). Similar genetic correlations were observed between average daily gain and visual scores $(0.60,0.57$ and 0.48 , respectively), whereas the genetic correlations between scrotal circumference and these scores were low $(0.13,0.02$, and 0.13$)$. The results indicate that visual scores can be used as selection criteria in Brahman breeding programs. Favorable correlated responses should be seen in average daily gain and body weight at 18 months. However, no correlated response is expected for scrotal circumference.
\end{abstract}

Key Words: average daily gain, body weight at 18 months, genetic correlation, heritability, scrotal circumference

\section{Introduction}

The combination of visual scores and growth traits usually measured in breeding programs is an important approach to identify animals with the best production performance. According to Koury Filho (2005), the inclusion of visual scores in selection programs is a suitable alternative to improve carcass quality, muscle mass distribution and finishing precocity. The advantage of this method is that a large number of animals can be evaluated without being subjected to the stress of measurements, a fact that makes the process faster and more viable economically (Jorge Júnior et al., 2001, 2004). However, one problem always related to visual scoring is that the results are evaluated subjectively by the human eye and are therefore prone to personal interpretation (Cardoso et al., 2004).

According to Koury Filho (2005), the application of visual scores in genetic breeding programs is feasible. Animal breeding programs evaluate the genetic quality of a certain population and estimate genetic correlations in an attempt to determine the impact on the genetic composition of future generations. In addition, breeding programs enable the selection of visual scores of body structure, precocity and muscularity and to predict the response that these traits will cause in other genetically correlated traits, thus enabling the determination of their effect on traits of interest.

Since visual scoring of body structure, precocity and muscularity is a recent visual assessment method, there are few studies correlating these traits with one another or with other economically important traits. Studies estimating genetic parameters for these visual scores are therefore needed. In Brazil, there are no scientific studies involving the Brahman breed, a fact that makes this investigation important for the development of this breed in the country. Therefore, the objectives of the present study were to estimate genetic parameters for body structure, precocity and muscularity in order to evaluate the possible use of these scores as selection criteria to improve carcass quality and to estimate correlations between visual scores and production and reproductive traits in order to evaluate the indirect response to selection. 


\section{Material and Methods}

Records of body weight at 18 months of age (W18), average daily gain, scrotal circumference and visual scores of body structure, precocity and muscularity collected according to the method of Koury Filho \& Albuquerque (2002) in Brahman cattle were used in the present study. Data were provided by the Brazilian Association of Zebu Breeders (ABCZ) and were from 1,116 animals, offspring of 191 reproducers and 794 dams. Data were collected during 39 collective weight gain tests on pasture conducted over a period of 294 days, with a minimum of 20 animals per test. The objective of this weight gain testing is to form precise contemporary groups. Only male animals with a genealogical record of birth can participate in the tests. The animals are fed forage feed, with supplementation during the dry period, if necessary. One of the components of the ranking index in the weight gain tests is evaluation by the EPMURAS method, which is performed at the end of all tests. A report with performance data of the animals and their respective rankings is then emitted.

Average daily gain was calculated as the difference between body weight at the beginning of the weight gain test after an adaptation period of 70 days and weight at the end of the test, divided by the total number of test days, i.e., 224 days. Records with no information or with values below three standard deviations were eliminated from the original dataset. Contemporary groups consisted of animals that participated in the same weight gain test (Table 1).

The following models were used: $y_{i}=m+p_{i}+a_{i}+e_{i}$ for body structure, precocity, muscularity and average daily gain; $y_{i}=m+p_{i}+b P f_{i}+b l f_{i}+a_{i}+e_{i}$ for scrotal circumference, and $y_{i}=m+p_{i}+b P i_{i}+a_{i}+e_{i}$ for weight at 18 months of age, in which: $\mathrm{m}=$ mean of the trait of the population; $p_{i}=$ fixed effect of contemporary group; $b P i_{i}=$ covariate of weight at the beginning of the test; $b P f_{i}=$ covariate of weight at the end of the test; $b l f_{i}=$ covariate of age at the end of the test; $a_{i}=$ direct additive genetic random effect; and $e_{i}=$ random residual effect.

The (co)variance components of the traits were estimated by the restricted maximum likelihood method in two-trait analysis using the MTDFREML software (Boldman et al., 1995).

\section{Results and Discussion}

Studies estimating heritabilities for body structure, precocity and muscularity in Brahman cattle are scarce. The heritabilities $\left(\mathrm{h}^{2}\right)$ obtained in the present study for the visual scores of body structure, precocity and muscularity were of high magnitude and similar, with estimates of 0.39 , 0.43 and 0.40 , respectively (Table 2 ). These scores obtained at 18 months of age suggest that there is sufficient additive genetic variation for selection and genetic progress in these traits. Similar results have been reported by Faria et al. (2009b), who evaluated Nellore cattle during the growth phase and estimated heritability values of $0.44,0.38$ and 0.32 for body sctructure, precocity and muscularity, respectively. Also studying Nellore cattle by visual scoring of body structure, precocity and muscularity, Koury Filho et al. (2006, 2009) reported different heritability: 0.24, 0.63 and 0.48, respectively. Yokoo et al. (2009) evaluated visual scores in Nellore cattle and also obtained moderate heritability for body structure (0.24) and high heritabilities for precocity and muscularity ( 0.63 and 0.48 , respectively).

Table 2 - Estimates of variance components and genetic parameters for body structure $(\mathrm{S})$, precocity $(\mathrm{P})$, muscularity (M), average daily gain (ADG), scrotal circumference (SC), and weight at 18 months of age (W18) obtained by two-trait analysis in Brahman cattle

\begin{tabular}{lcccc}
\hline Trait & $\sigma_{\mathrm{a}}^{2}$ & $\sigma_{\mathrm{e}}^{2}$ & $\sigma_{\mathrm{p}}^{2}$ & $\mathrm{~h}^{2}$ \\
\hline $\mathrm{S}$ & 0.41 & 0.65 & 1.06 & 0.39 \\
$\mathrm{P}$ & 0.40 & 0.54 & 0.94 & 0.43 \\
$\mathrm{M}$ & 0.43 & 0.64 & 1.07 & 0.40 \\
$\mathrm{ADG}$ & 0.0039 & 0.0079 & 0.01 & 0.33 \\
$\mathrm{SC}$ & 4.08 & 1.27 & 5.35 & 0.76 \\
$\mathrm{~W} 18$ & 303.31 & 329.57 & 632.88 & 0.48 \\
\hline$\sigma^{2}{ }_{\mathrm{a}}$-direct additive genetic variance; $\sigma^{2}{ }_{\mathrm{e}}$-random residual variance; $\sigma^{2}{ }_{\mathrm{p}}$ - - phenotypic \\
variance; ${ }^{2}$ - heritability.
\end{tabular}

Table 1 - Descriptive statistics of body structure (S), precocity (P), muscularity (M), average daily weight gain (ADG), scrotal circumference, and weight at 18 months of age (W18) in Brahman cattle

\begin{tabular}{|c|c|c|c|c|c|c|}
\hline Trait & $\mathrm{N}$ & Mean & $\mathrm{SD}$ & CV (\%) & Minimum & Maximum \\
\hline $\mathrm{S}$ & 1,116 & 4.02 & 1.12 & 27.99 & 1.0 & 6.0 \\
\hline $\mathrm{P}$ & 1,116 & 3.98 & 1.05 & 26.41 & 1.0 & 6.0 \\
\hline M & 1,116 & 3.78 & 1.14 & 30.24 & 1.0 & 6.0 \\
\hline ADG (kg) & 1,116 & 0.49 & 0.18 & 38.37 & -0.37 & 1.18 \\
\hline $\mathrm{SC}(\mathrm{cm})$ & 541 & 28.33 & 3.51 & 12.39 & 19.0 & 39.0 \\
\hline W18 (kg) & 1,116 & 363.24 & 48.68 & 13.40 & 111.32 & 540.46 \\
\hline
\end{tabular}

$\mathrm{N}$ - number of observations; SD - standard deviation; CV - coefficient of variation.

R. Bras. Zootec., v.41, n.6, p.1407-1411, 2012 
The heritability for average daily gain was of medium magnitude (Table 2) and higher than those reported by Costa et al. (2008) for Brangus cattle and by Cardoso et al. (2001) for weaning weight gain for Angus cattle (0.18 and 0.20 , respectively).

Medium to high heritability has been reported in the literature for scrotal circumference at 550 days of age (18 months), with estimates of 0.31 (Gressler et al., 2000), 0.34 (Garnero et al., 2001), 0.46 (Costa et al., 2004), and 0.77 (Quirino \& Bergmann, 1998). The last estimate is similar to that observed in the present study (0.76), indicating greater genetic variability at 18 months, a fact favoring selection for this age.

The heritability for weight at 18 months of age was high (Table 2), suggesting that genetic progress is possible when selecting for this trait. This trait is widely used by breeders as a selection criterion because of its high association with slaughter weight. Heritabilities for weight at 18 months of age of low to medium magnitude have been reported in the literature for the Tabapuã (0.15) (Ferraz Filho et al., 2002) and Nellore breed (0.29) (Koury Filho et al., 2009). In contrast, Ribeiro et al. (2001) found high heritability (0.76) of this trait in Nellore cattle.

In the present study, high phenotypic correlations were observed between visual scores of body structure, prococity and muscularity ( 0.59 to 0.71 ), medium to high correlations between visual scores and production traits ( 0.40 to 0.57 ), low correlations between visual scores and scrotal circumference (-0.0002 to 0.03$)$, and a high correlation between production traits $(0.85)$ (Table 3 ). These results indicate that animals with a good body structure, finishing precocity and muscle mass have higher weight at 18 months of age and average daily gain. However, no association was observed with scrotal circumference. This finding can be explained by the low genetic correlation between scrotal circumference and the other traits, a fact resulting in low phenotypic correlation.

Table 3 - Estimates of additive genetic (below the diagonal) and phenotypic (above the diagonal) correlations between body structure $(\mathrm{S})$, precocity $(\mathrm{P})$, muscularity $(\mathrm{M})$, average daily gain (ADG), scrotal circumference (SC), and weight at 18 months of age (W18) obtained by two-trait analysis in Brahman cattle

\begin{tabular}{lcccccc}
\hline Trait & S & P & M & ADG & SC & W18 \\
\hline S & 1 & 0.61 & 0.59 & 0.41 & -0.0002 & 0.57 \\
P & 0.79 & 1 & 0.71 & 0.40 & -0.02 & 0.42 \\
M & 0.87 & 0.91 & 1 & 0.40 & 0.03 & 0.52 \\
ADG & 0.60 & 0.57 & 0.48 & 1 & -0.19 & 0.85 \\
SC & 0.13 & 0.02 & 0.13 & 0.09 & 1 & -0.08 \\
W1 8 & 0.77 & 0.57 & 0.59 & 0.73 & -0.02 & 1 \\
\hline
\end{tabular}

The genetic correlations between the visual scores of body structure, prococity and muscularity were high (0.79 to 0.91 ), indicating that these scores are mainly controlled by the same groups of genes. These findings agree with Koury Filho et al. (2009), who estimated genetic correlations of 0.49 between body structure an precocity, of 0.63 between body structure and muscularity, and of 0.90 between precocity and muscularity in Nellore cattle. Costa et al. (2008) analyzed visual scores of body conformation, precocity and muscularity in Brangus cattle and found positive association between weaning visual scores, with genetic correlations of 0.92 or higher. Genetic correlations obtained at weaning and yearling higher than 0.90 between body conformation, precocity and muscularity have also been reported by Cardoso et al. (2001) for Brangus cattle. Using the method of visual scoring of body conformation, precocity and muscularity, Koury Filho (2005) reported moderate to high positive genetic correlations between visual scores ( 0.49 to 0.95 ). In addition, body conformation, precocity and muscularity promoted an increase in weaning and yearling weight, which allows the adoption of these indices in the selection process. According to Cardoso et al. (2004), high genetic correlations between visual scores of body conformation, precocity and muscularity are expected, since body conformation comprises aspects of muscle mass, size, and finishing.

Genetic correlations of $0.60,0.57$ and 0.48 were observed between body structure, precocity and muscularity scores and average daily gain, respectively. These estimates are slightly lower than those reported by Costa et al. (2008), who studying the CPM method, obtained genetic correlations between weight gain for Brangus cattle from birth to weaning and bodyconformation, precocity and muscularity scores of 0.65 to 0.81 . Although the estimates obtained here are lower than those reported in the literature, they suggest that selection for visual scores will result in an increase of daily weight gain.

The genetic correlations between visual scores and scrotal circumference ranged from 0.02 to 0.13 . In contrast, higher genetic correlations between visual scores of muscularity, physical structure and conformation and scrotal circumference have been reported by Faria et al. (2009a) for animals evaluated at 15 months of age (0.24 to $0.65)$. The low association between these traits found in the present study can be explained by the use of the covariates age and weight of the animal to correct for scrotal circumference. These low correlations show that the genetic determination of scrotal circumference does not depend on weight or visual score traits. Therefore, higher selection intensities can be applied to visual 
scores without producing undesired correlated responses in scrotal circumference or mature size.

Inversely, greater genetic progress in sexual precocity could be obtained when the correlated response in growth velocity (Ortiz Peña et al., 2001) and visual scores is low. These low correlations are therefore favorable to animal breeding programs by simplifying selection for important traits such as sexual precocity (using scrotal circumference as an indicator trait), mature size and body scores, since the aim is not to obtain maximum values, but intermediate values that are considered to be ideal.

The genetic correlations between body structure, precocity and muscularity scores and weight at 18 months of age $(0.77,0.57$ and 0.59 , respectively) confirm that selection for visual scores, particularly body structure, should promote an increase in weight at 18 months of age. These scores can therefore be used as criteria for the selection of reproducers. These findings agree with Koury Filho et al. (2009) who also obtained high and positive genetic correlations ( $0.83,0.42$ and 0.50 , respectively) between body structure, precocity and muscularity scores and yearling weight (approximately 550 days of age).

The correlations between scrotal circumference and average daily gain (0.19) and between scrotal circumference and weight at 18 months of age (-0.02) indicate a low association between these traits. In contrast, Pereira et al. (2001) observed that scrotal circumference and weight performance traits are correlated in Nellore cattle, i.e., selection for higher weight and weight gain would result in higher scrotal circumference. The divergence in the estimates found in the present study and those reported by Pereira et al. (2001) can be explained by the genetic evaluation model used here, which included age and weight of the animal as covariates (correction for age and weight). As a consequence, most of the genetic correlation of scrotal circumference with average daily gain and weight at 18 months of age is eliminated. In contrast, the model used by Pereira et al. (2001) only included age as covariate and the genetic correlations of scrotal circumference with average daily gain and weight at 18 months of age were therefore significantly higher than the data obtained in this study (Table 3).

The high correlation between weight at 18 months of age and average daily gain (0.73) suggests that selection for one of these traits will promote gain in the other trait, hence these traits being highly associated, except for SC.

\section{Conclusions}

The visual scores of structure, precocity and muscularity can be used as selection criteria, once they show high heritability. The existence of positive and desired correlations with growth traits (body weight at 18 months and average daily gain) indicates an indirect response to selection, which would contribute to increase the genetic progress of the Brahman population studied here. However, no correlated response is expected for scrotal circumference.

\section{Acknowledgements}

The authors thank the colleagues of the Laboratory LuCCA-Z of Unesp Dracena, the ABCZ for providing the dataset and FAPESP for financial support.

\section{References}

BOLDMAN, KG.; KRIESE, L.A.; VAN VLECK, L.D. et al. A manual for use of MTDFREML: a set of programs to obtain estimates of variances and covariances (DRAFT). Lincoln: Department of Agriculture, Agricultural Research Service, 1995.

CARDOSO, F.F.; CARDELLINO, R.A.; CAMPOS, L.T. Componentes de (co)variância e parâmetros genéticos de caracteres pósdesmama em bovinos da raça Angus. Revista Brasileira de Zootecnia, v.33, n.2, p.313-319, 2004.

CARDOSO, F.F..; CARDELLINO, R.A.; CAMPOS, L.T. et al. Componentes de (co)variância e parâmetros genéticos para caracteres produtivos à desmama de bezerros Angus criados no Estado do Rio Grande do Sul. Revista Brasileira de Zootecnia, v.30, n.1, p.41-48, 2001.

COSTA, R.B.; LAUREANO, M.M.M.; FORNI, S. et al. Estimativas de parâmetros genéticos para as características perímetro escrotal, peso ao sobreano e idade ao primeiro parto em um rebanho da raça Nelore, 2004. In: SIMPÓSIO DA SOCIEDADE BRASILEIRA DE MELHORAMENTO ANIMAL, 5., Pirassununga. Anais... Pirassununga: SBMA, 2004. (CD-ROM).

COSTA, G.Z.; QUEIROZ, S.A.; OLIVEIRA, J.A. et al. Estimativas de parâmetros genéticos e fenotípicos de escores visuais e de ganho médio de peso do nascimento a desmama de bovinos formadores da raça Brangus. Ars Veterinaria, v.24, n.3, p.172-176, 2008.

FARIA, C.U.; MAGNABOSCO, C.U.; ALBUQUERQUE, L.G. et al. Análise bayesiana na estimação de correlações genéticas entre escores visuais e características reprodutivas de bovinos Nelore utilizando modelos linear-limiar. Arquivo Brasileiro de Medicina Veterinária e Zootecnia, v.61, n.4, p.949-958, 2009a.

FARIA, C.U.; KOURY FILHO, W.; MAGNABOSCO, C.U. et al. [2009b] Bayesian inference in genetic parameter estimation of visual scores in Nellore beef-cattle. Genetics and Molecular Biology. Available at: <http://www.scielo.br/pdf/gmb/2009nahead/ 2008-275.pdf >. Accessed on: July 1, 2010.

FERRAZ FILHO, P.B.; RAMOS, A.A.; SILVA, L.O.C. et al. Herdabilidade e correlações genéticas, fenotípicas e ambientais para pesos em diferentes idades de bovinos da raça Tabapuã, Archives of Veterinary Science, v.7, n.1, p.65-69, 2002.

GARNERO, A.V.; LÔBO, R.B.; BEZERRA, L.A.F. et al. Comparação entre alguns critérios de seleção para crescimento na raça Nelore. Revista Brasileira de Zootecnia, v.30, n.3, p.714-718, 2001.

GRESSLER, S.L.; BERGMANN, J.A.G.; PEREIRA, C.S. et al. Estudo das associações genéticas entre perímetro escrotal e características reprodutivas de fêmeas Nelore. Revista Brasileira de Zootecnia, v.29, n.2, p.427-437, 2000.

JORGE JÚNIOR, J.; DIAS, L.T.; ALBUQUERQUE, L.G. Fatores de correção de escores visuais de conformação, precocidade e musculatura, à desmama, para idade da vaca ao parto, data juliana 
de nascimento e idade à desmama em bovinos da raça Nelore. Revista Brasileira de Zootecnia, v.33, n.6, p.2044-2053, 2004.

JORGE JÚNIOR, J.; PITA, F.V.C.; FRIES, L.A. et al. Influência de alguns fatores de ambiente sobre os escores de conformação, precocidade e musculatura à desmama em um rebanho da raça Nelore. Revista Brasileira de Zootecnia, v.30, n.6, p.1697-1703, 2001.

KOURY FILHO, W. Escores visuais e suas relações com características de crescimento em bovinos de corte. 2005. 80f. Tese (Doutorado em Zootecnia) - Faculdade de Ciências Agrárias e Veterinárias, Universidade Estadual Paulista, Jaboticabal.

KOURY FIlHo, W.; Albuquerque, L.G. Proposta de metodologia para coleta de dados de escores visuais para programas de melhoramento. In: CONGRESSO BRASILEIRO DAS RAÇAS ZEBUÍNAS, 5., 2002, Uberaba. Anais... Uberaba, 2002. p.264-266.

KOURY FILHO, W.; ALBUQUERQUE, L.G.; ALENCAR, M.M. et al. Genetic parameter estimates of visual score traits and their relationship with growing traits in Brazilian Nelore cattle. In: WORLD CONGRESS ON GENETICS APPLIED TO LIVESTOCK PRODUCTION, 8., 2006, Belo Horizonte Anais... Belo Horizonte: Instituto Prociência, 2006.
KOURY FILHO, W.; ALBUQUERQUE, L.G.; ALENCAR, M.M. et al. Estimativas de herdabilidade e correlações para escores visuais, peso e altura ao sobreano em rebanhos da raça Nelore. Revista Brasileira de Zootecnia, v.38, n.12, p.2362-2367, 2009.

ORTIZ PEÑA, C.D.; QUEIROZ, S.A.; FRIES, L.A. Comparação entre critérios de seleção de precocidade sexual e a associação destes com características de crescimento em bovinos Nelore. Revista Brasileira de Zootecnia, v.30, n.1, p.93-100, 2001.

PEREIRA, E.; ELER, J.P.; FERRAZ, J.B.S. Análise genética de algumas características reprodutivas e suas relações com o desempenho ponderal na raça Nelore. Arquivo Brasileiro de Medicina Veterinária e Zootecnia, v.53, n.6, p.720-727, 2001.

QUIRINO, C.R.; BERGMANN, J.A.G. Heritability of scrotal circumference adjusted and unadjusted for body weight in Nellore bulls using ani and bivariate animal models. Theriogenology, v.48, n.7, p.1398-1396, 1998.

RIBEIRO, M.N.; PIMENTA FILHO, E.C.; MARTINS, G.A. et al. Herdabilidade para efeitos direto e materno de características de crescimento de bovinos Nelore no estado de Paraíba. Revista Brasileira de Zootecnia, v.30, n.4, p.1224-1227, 2001.

YOKOO, M.J.I.; WERNECK, J.N.; PEREIRA, M.C. et al. Correlações genéticas entre escores visuais e características de carcaça medidas por ultrassom em bovinos de corte. Pesquisa Agropecuária Brasileira, v.44, p.197-202, 2009. 